\title{
Drip water measurements from Carlsbad Cavern: implications towards paleoclimate records yielded from evaporative-zone stalagmites
}

\author{
Victor J. Polyak ${ }^{1}$, Jessica B.T. Rasmussen ${ }^{2}$, and Yemane Asmerom ${ }^{1}$ \\ ${ }^{1}$ Department of Earth \& Planetary Sciences, University of New Mexico, Albuquerque, New Mexico 87131, USA \\ ${ }^{2} 533$ Paseo del Pueblo, Taos, New Mexico 87571, USA
}

\begin{abstract}
Stalagmites can host numerous potential climate proxies (stable and radiogenic isotopes, trace elements, annual and non-annual banding, grayscale, growth hiatuses, mineral assemblage). Reproducibility and/or integration of proxy results between one or more stalagmites will become increasingly important, and ideally, climate records generated by multiple stalagmites from the same cave or cave room are expected to be near-identical. The reality is that stalagmites from the same cave room can yield differing results to some degree, especially in cave environment zones that are evaporative. Our drip water study in an evaporative shallow-depth cave environment in Carlsbad Cavern shows that adjacent drip sites produce differing drip rate behavior, but share some similarities. Drip water collected from four sites in this evaporative cave environment shows $\mathrm{Ca}, \mathrm{Mg}, \mathrm{Sr}, \mathrm{Ba}, \mathrm{U}$, and $\mathrm{Th}$ elemental concentrations and ${ }^{234} U /{ }^{238} U$ (expressed as $\delta^{234} U$ ) to vary seasonally, and all but $U$ have higher values during the winter months when the instrumented cave site exhibited slower drip rates and was drier. Results from our Carlsbad Cavern drip sites indicate that increased relative humidity in the cave and decreased surface and cave atmospheric pressure combined with increased precipitation (rain and snow) are responsible for faster drip rates. Changes in atmospheric pressure play an essential role, although less directly during summer months. We therefore conclude that stalagmites within the same cave room may not record and produce identical proxy records in these more evaporative cave environments, but that differing records are simply recording the same climate signals expressed uniquely by the individual proxies, and that each stalagmite simply has differing sensitivities to the climate signals. Integrated, these proxy differences serve as important past climate indicators. Our drip sites respond to seasonal variations in climate more so than individual rain/snow events, and we favor the interpretation that seasonal changes reflect regional as well as local climate changes.
\end{abstract}

Keywords: $\quad$ cave, drip water, Carlsbad Cavern, climate, uranium isotopes

Received 7 July 2017; Revised 3 April 2018; Accepted 5 April 2018

Citation: Polyak V.J., Rasmussen J.B.T. and Asmerom Y., 2018. Drip water measurements from Carlsbad Cavern: implications towards paleoclimate records yielded from evaporative-zone stalagmites. International Journal of Speleology, 47 (2), 201-212. Tampa, FL (USA) ISSN 0392-6672 https://doi.org/10.5038/1827-806X.47.2.2144

\section{INTRODUCTION}

Stalagmites as paleoclimate indicators are advantageous in many ways over other indicators, producing some of the most robust and highly resolved records globally. Yet understanding the hydrological processes from the surface soil to the stalagmite lags behind the production of paleoclimate records, and this creates a need for more cave environment studies (Beddows et al., 2007). The numerous cave climate and drip studies that have been conducted leave researchers with countless questions related to stalagmite climate proxy reproducibility, correlation to precipitation and temperature, and effects due to ventilation, but with each study making valuable contributions towards understanding how cave climate translates into local and regional paleoclimate (Genty \& Deflandre, 1998; Baldini et al., 2006; Fairchild et al., 2006; Verheyden et al., 2008; Poulain et al., 2015; Duan et al., 2016). Smart \& Friedrich (1987), Baker et al. (1997), and Baldini et al. (2006) have produced widely accepted drip site classifications based on drip discharge and cave environment where drip rates of one drip per 1-1000 seconds are considered seepage flow and seasonal drip types, the classifications that our drip study falls under. 
Some studies of seepage flow and seasonal drip type dripping include multiple sites and show different dripping behaviors of these sites. Three drip sites from a cave in Belize show two sites with less drip rate variability having low drip rates $(<35$ drips/hr) and one site with high variability having drip rates $>200$ drips /hr (Ridley et al., 2015). Ten drip sites in Australian caves monitored by McDonald \& Drysdale (2007) at different depths showed that increased bedrock overburden complicated the drip systems. A comprehensive study that includes 34 drip sites in 8 caves that covers a large region (southeastern China) has identified three types of drip sites based on $\delta^{18} \mathrm{O}$ variability of drip water but with drip rate data included, and conclude that different hydrologic conditions associated with these three drip site types are important when considering interpretation of $\delta^{18} \mathrm{O}$ variability in the stalagmites that grow under these sites (Duan et al., 2016). Six drip sites from Westcave Preserve in central Texas that include drip rate and elemental concentration data were intensively studied in an evaporative cave environment (Casteel \& Banner, 2014) somewhat similar to our Carlsbad Cavern sites. Evaporative cave zones, however, are still largely avoided by paleoclimatologists because of problems related to kinetic fractionation of carbon and oxygen isotopes during calcite/aragonite crystallization (Lachniet, 2009, 2015), and consequently stalagmite samples from deep cave zones where relative humidity is perennially close to $100 \%$ are preferred. Nonetheless, stalagmites in somewhat evaporative zones are used as relative indicators of rainfall where kinetic fractionation can enhance the rainfall signal. Stalagmites from evaporative cave zones preserve added complexities, but also potentially hold additional benefits beyond relative rainfall indicators. Drip rate studies in these evaporative sites should yield beneficial information regarding the use of these cave zones in paleoclimate studies. Here we present results of a drip study from an instrumented site in Carlsbad Cavern, New Mexico USA that is evaporative and has yielded significant paleoclimate records covering the past two millennia of climate change (Polyak \& Asmerom 2001; Rasmussen et al., 2006; Asmerom et al., 2013). These results contribute to our understanding of the drip system and stalagmite growth in evaporative cave environments such as those common to the Guadalupe Mountains caves of southeastern New Mexico and West Texas, USA.

We collected two years of hourly drip water data along with hourly temperature, relative humidity, and atmospheric pressure data from Carlsbad Cavern. These data were collected from the Main Corridor at the intersection of Bat Cave passage, where stalagmites $\mathrm{BC} 2$ and $\mathrm{BC} 11$ were collected (Fig. 1; Rasmussen, 2006). These stalagmites have produced important paleoclimate records published previously (Polyak \& Asmerom, 2001; Rasmussen et al., 2006; Asmerom et al., 2013). We used seismic technology to count drips. Mg,
$\mathrm{Sr}, \mathrm{Ba}, \mathrm{Ca}, \mathrm{U}$, and Th elemental concentrations and $\delta^{234} \mathrm{U}$ and ${ }^{230} \mathrm{Th} /{ }^{232} \mathrm{Th}$ isotopic values of the drip water were measured. Carbon and oxygen stable isotope values were not measured due to the collection method that was not intended for stable isotope studies (the collection bottles were not capped and no paraffin oil was added to prevent evaporation prior to collection).

The cave environment of our study site is an evaporative near-entrance zone where cold winter air sinking into the large entrance of Carlsbad Cavern affects the instrumented sites (see Fig. 1). Since most caves in the Guadalupe Mountains have evaporative environments, previous stalagmite studies of Polyak $\&$ Asmerom (2001), Polyak et al. (2001); Rasmussen et al. (2006), Asmerom et al. (2007) and Asmerom et al. (2013) used samples from evaporative near-entrance cave zones with the premise that these samples will better preserve a more direct link to surface climate changes. This near-entrance cave zone is where most annually banded stalagmites grow. Our instrumented sites in Carlsbad Cavern experience relatively large swings in temperature, relative humidity, atmospheric pressure, and drip rate during the winter months related to cold winter air sinking into the cave. The monitoring period for this study (May 2002 to September 2004) overlapped with the 2002 and 2004 El Niño events and a short-lived shift from negative to positive Pacific Decadal Oscillation (PDO), both of which provide the southwestern United States with greater precipitation (Rasmussen, 2006). Surface precipitation during the monitoring period was near

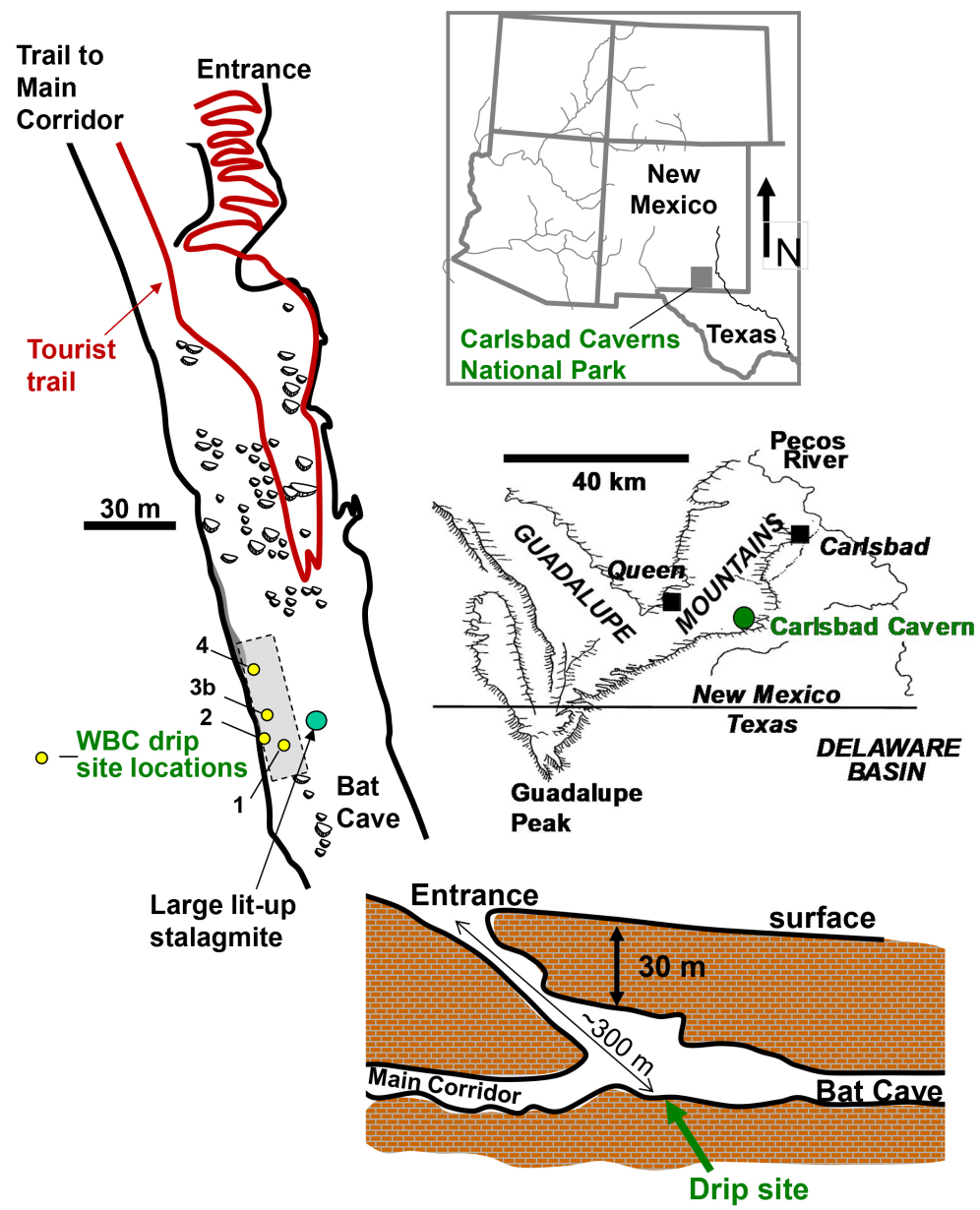

Fig. 1. Study area in Carlsbad Cavern. Drip site area is below the main entrance where rock overburden is thinnest. 
normal during 2002, very dry during $2003 \mathrm{CE}$, and above normal during 2004. Four drip sites, WBC1, $\mathrm{WBC} 2, \mathrm{WBC} 3 \mathrm{~b}$, and $\mathrm{WBC} 4$, were instrumented (Figs. 1 and 2).

The Guadalupe Mountains range in elevation from $2667 \mathrm{~m}$ at Guadalupe Peak on the southwestern end of the mountains to $1340 \mathrm{~m}$ at Carlsbad Cavern on the northeastern end. The area is semi-arid, forested at higher elevations and covered with desert vegetation (cactus and desert shrubs) at Carlsbad Cavern. As much as $50 \%$ of the $380 \mathrm{~mm}$ of annual precipitation comes from the North American Monsoon summer rains from July to September (Leavitt et al., 2011). The El Niño phase of the El Niño Southern Oscillation (ENSO) brings extra winter and spring precipitation to the study area every 2 to 8 years, and particularly when El Niño is in phase with the Pacific Decadal Oscillation (PDO; Wang et al., 2014).

\section{METHODS}

We used accelerometers to count drips, where all individual drips are counted as drips per hour. An accelerometer was attached to a Plexiglas paddle that was tilted so that each drip that strikes the paddle produces an event that is recorded by an Omega NOMAD OM-CP-PULSE101 datalogger (Fig. 2). The sensitivity of the accelerometer was adjusted so that aftershocks were not recorded. The water from these drips flows down the paddle and into a one-liter bottle for collection. The small size of the bottle neck significantly dampens evaporative effects relative to open bottles. Drip rates were sufficiently slow that

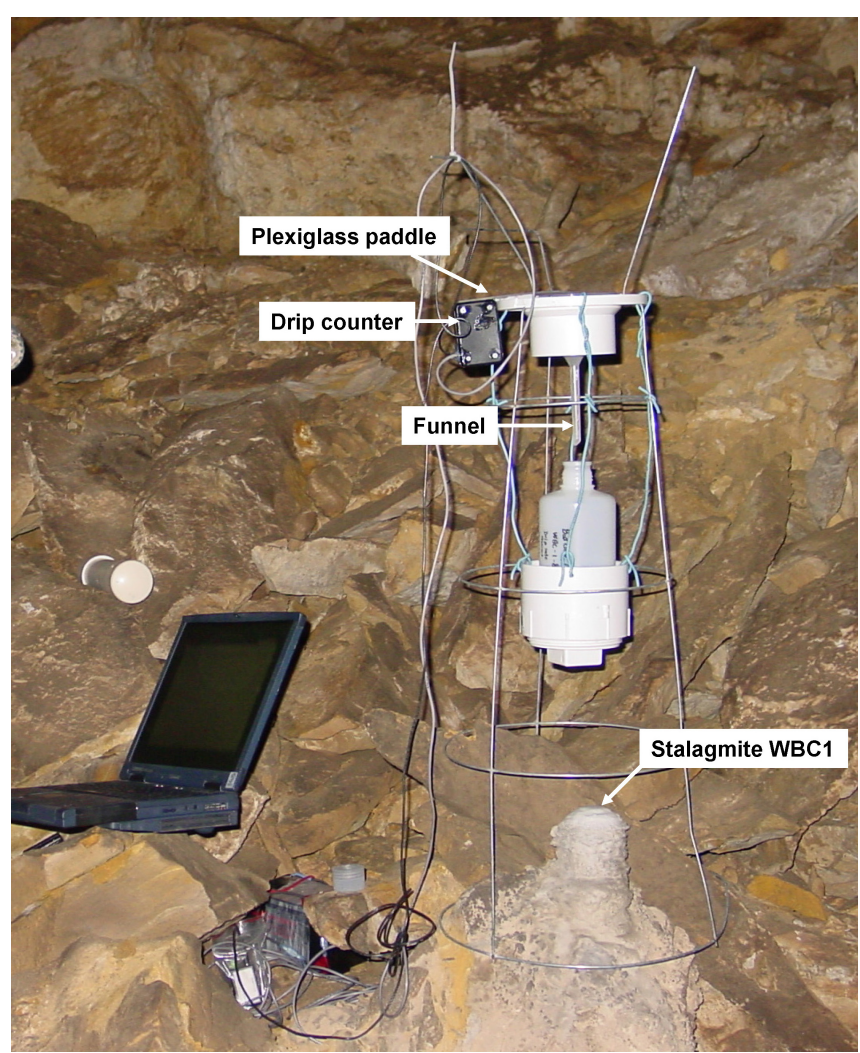

Fig. 2. Drip rate monitor set up at site WBC4 (left) and WBC1 (right) in Carlsbad Cavern. An accelerometer attached to a Plexiglas paddle registered each drip, and drips were counted per hour. Water descends into a funnel and is collected. A 6-V motorcycle battery used to supply electrical energy was exchanged monthly. the bottles did not over-fill at the end of a one-month period, except during the summer humid months in some cases. An Omega NOMAD OM-CP-PRHTEMP101 temperature, relative humidity, and atmospheric pressure datalogger was placed near the drip counters. The two dataloggers, the one for drip counts and the other for climatology, were independently recording data at hourly resolution. Each drip counter was powered with a $6 \mathrm{~V}$ motorcycle battery that lasted one month. Dataloggers were downloaded and batteries exchanged each month.

$\mathrm{Mg}, \mathrm{Sr}, \mathrm{Ba}$, and $\mathrm{Ca}$ elemental concentrations were determined by inductively coupled mass spectrometry (ICPMS) on a Fison VG PQ-2 (Rasmussen, 2006) and Thermo X-series II ICPMS. U and Th concentrations, $\delta^{234} \mathrm{U}$, and ${ }^{230} \mathrm{Th} /{ }^{232} \mathrm{Th}$ were measured on a Thermo Neptune multicollector (MC) ICPMS. Samples run on our MC-ICPMS were prepared and analyzed using our standard methods described in Polyak et al. (2012) and Asmerom et al. (2013). The drip study was not designed for stable isotope measurements.

\section{RESULTS}

Of our four monitored drip sites, site WBC1 fed stalagmite $\mathrm{BC} 8$, and site $\mathrm{WBC} 4$ fed stalagmite $\mathrm{BC}$. Both of these stalagmites were collected. The other two drip sites, WBC2 and WBC3b were set up where stalagmites likely existed but were detached when the area was damaged by early visitors to the cave decades before our study. This area is decorated with many stalagmites, stalactites, columns, and flowstone, but located in the path of bat guano miners from 1906 to 1924 and the first tourists that rode the guano bucket down the Bat Cave entrance to bypass the vertical drop at the main entrance from 1924 until 1926 when the stairs were built (Nymeyer \& Halliday, 1991). As a result, much damage was done to these galleries, although Asmerom et al. (2013) dated the top of stalagmite BC2 to be 1970 $\mathrm{CE}$, indicating that stalagmite $\mathrm{BC} 2$ was broken after the stairs going into the main entrance were installed. All of the drip sites and the temperaturehumidity-pressure datalogger are located within a 50-meter perimeter along the south wall of the passage (Fig. 1).

\section{Monitored cave site climatology and drip rates}

Drip water monitoring sites included WBC1, WBC2, WBC3b, and WBC4 (Fig. 1). Climatology of the monitored cave site (Carlsbad Cavern) versus surface climate monitored at the city of Carlsbad municipal airport $26 \mathrm{~km}$ east of the cave show positive correlations as expected. The temperature time-series in the cave versus that on the surface has a high correlation ( $R=0.84$; Rasmussen, 2006). The cave relative humidity time-series versus surface also exhibits a positive correlation, although weaker $(\mathrm{R}=0.28$; Rasmussen, 2006). Atmospheric pressure time-series of the surface and cave site are almost identical ( $\mathrm{R}=0.99$; Rasmussen, 2006), with the cave pressure slightly higher, a similar scenario to that measured by McCann (2013) in a Guam Cave. The 
monitored cave site in Carlsbad Cavern experiences increased temperature and relative humidity during the warmer, more humid monsoonal summer months. Sites $\mathrm{WBC} 1$ and $\mathrm{WBC} 3 \mathrm{~b}$ had ceilings too high to observe the origin of dripping. Sites WBC2 and WBC4 had no obvious soda straws or stalactites that could be observed over the drip sites, partly because of damage done to the site by early mining or tourism. The two longer-record drip sites are compared to daily precipitation that is based on the average of three nearby climatological stations, Queen, Carlsbad, and Carlsbad Caverns obtained from the Western Regional Climate Center (2013). All drip sites produce a seepage flow type drip, with the exception of drip site WBC2, which can be categorized as a seasonal drip type because this site quits dripping in the winter months (Fig. 3).

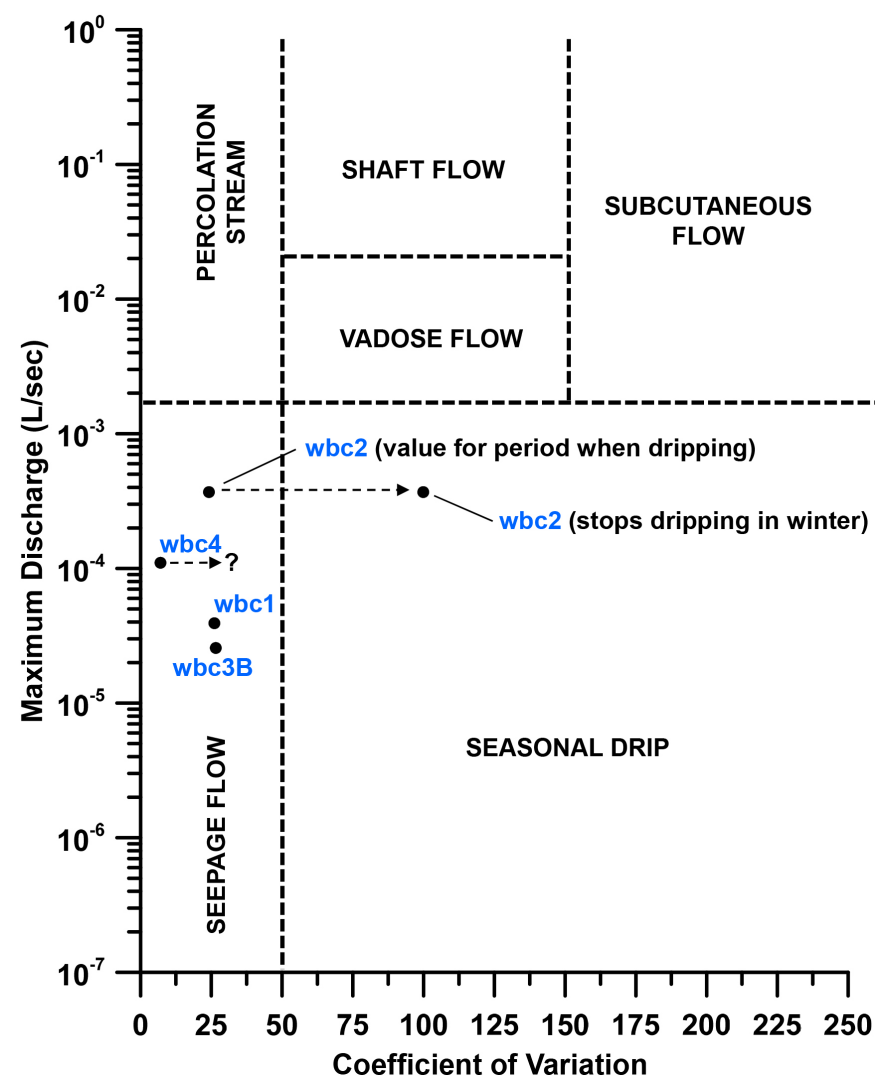

Fig. 3. Drip type classification from maximum measured drip rate (liters/ second) versus coefficient of variation (standard deviation/mean *100). See Baldini et al. (2006). Three of the four drip sites fall into the seepage flow type drip category. Drip site WBC2, however, quit dripping during the winter months, and when that period of non-dripping is included with the period of dripping, the coefficient of variation increases and the results plot in the seasonal drip category. For the period of dripping, drip site WBC2 plots in the seepage flow classification. Drip site WBC4 is similar to WBC2, where missing data (available only by manual drip rate measurements) would produce greater coefficient of variation. Drip sites WBC2 and WBC4 have assumed drip volumes of $0.1 \mathrm{ml}$.

Drip site WBC1 dripped continuously over the two-year monitoring period. The drip rate changed seasonally by $\sim 10$ drips per hour, with warmer, more humid summer months coincident with higher drip rates (Fig. 4). While this drip site dripped continuous over the two-year monitoring period, our preliminary examination of stalagmite $\mathrm{BC} 8$ below this drip site exhibited discontinuous growth with hiatuses illustrating that the current drip period was likely not continuous in much of the late Holocene. The tip

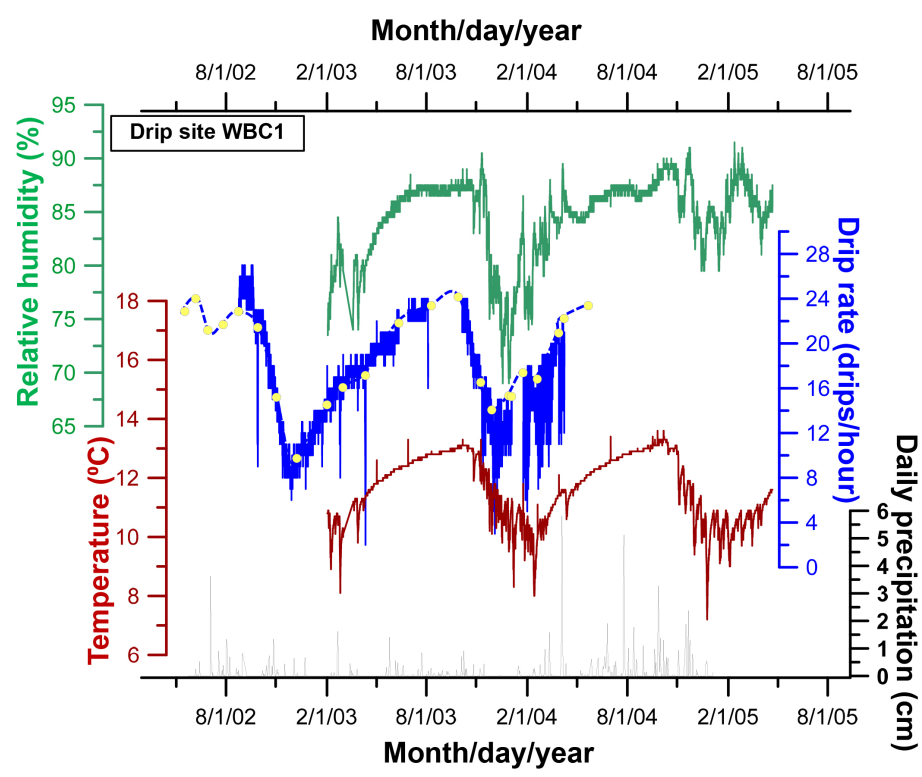

Fig. 4. Drip rate record for site WBC1 compared to cave relative humidity, cave temperature, and daily surface precipitation records for the same period. Surface precipitation (rainfall) data are from Western Regional Climate Center (2013). Yellow circles and blue dashed curve represent manually measured drip rate data.

of this stalagmite visually indicates that the top is modern calcite, and there was some calcite deposited on the paddle of the drip rate counter. Two years of manually measured and instrumented drip data were collected at this site.

Drip site WBC2 stopped dripping during both winters of the monitoring period (Fig. 5). The drip rate at this site was higher by a factor of 3 to 10 over site WBC 1 and varied from 0 to 280 drips per hour (Fig. 4). This site is obviously far more sensitive to seasonal climatological changes. One could assume from this drip data that a stalagmite under this drip site would exhibit more growth rate variability in response to climatic swings. The drip rate at this site peaked long before the cave temperature and humidity peaked, and before site WBC1 drip rate peaked. Two years of manually measured drip data and one year of instrumented data were collected.

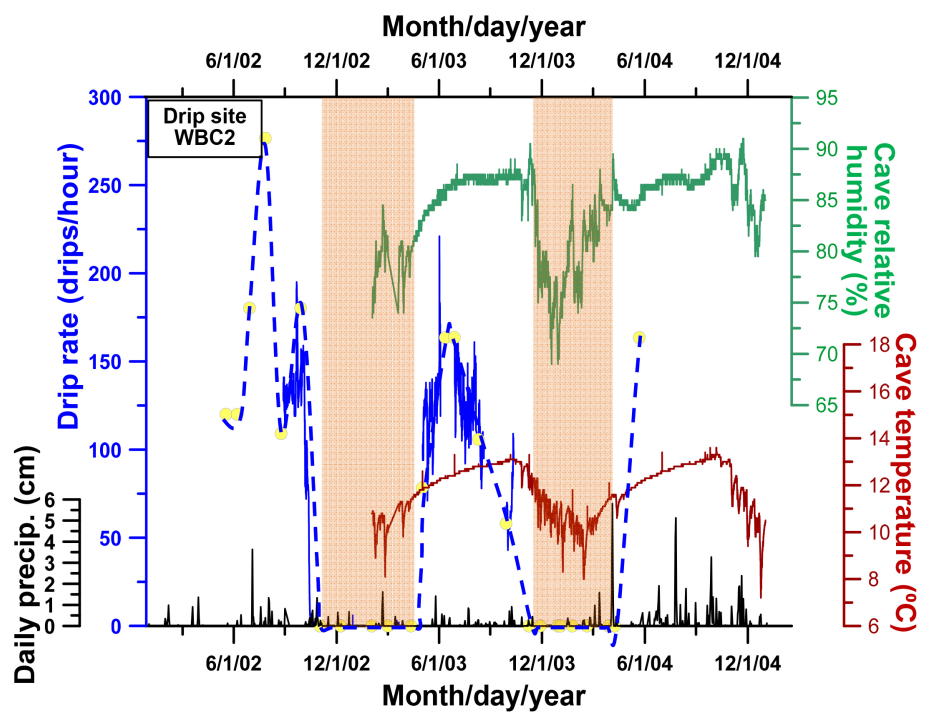

Fig. 5. Temperature, relative humidity, and site WBC2 drip rate show that seasonal variations correlate well with drip rate. The WBC2 drip site stopped dripping in both winters that were monitored. Note that the drip rate is exceptionally higher for site WBC2. Yellow circles and blue dashed curve represent manually measured drip rate data. 
Drip site $\boldsymbol{W B C} \mathbf{B b}$ dripped continuously over the monitoring period, and behaved similar to site WBC1 (Fig. 6). Both sites exhibit a similar drip rate between 5 and 25 drips per hour. Almost two years of drip data were collected at this site, but there are gaps due to instrument problems.

Drip site WBC4 dripped continuously over the monitoring period. The drip rate varied between 25 and 70 drips per hour (Fig. 7). This drip site fed stalagmite $\mathrm{BC} 7$, which has a fast growth rate. Stalagmite BC7 was a broken stub with recently precipitated calcite growth on the broken surface. The stalagmite was likely broken during guano mining operations, or by the earliest tourists within the last 110 years, and a $\mathrm{U}$-series date on this new growth is $30 \pm 100$ yrs BP. The recent calcite deposit exhibits faint annual banding from which the age of this overgrowth on the stub was determined to be $64 \pm 10$ yrs BP with a growth rate of $147 \mu \mathrm{m} /$ year (Rasmussen, 2006). The stub represents a segment of Late Holocene growth between 2900 and 1900 years ago that has a faster growth rate of $\sim 300 \mu \mathrm{m} /$ year. About $1 \frac{1 / 2}{2}$ years of manually measured drip rate data and less than a year of instrumented data were collected,

\section{Elemental concentrations and U-series values}

$\mathrm{Ca}, \mathrm{Mg}, \mathrm{Sr}, \mathrm{Ba}$, and $\mathrm{U}$ concentrations of two years of monthly drip water samples show higher elemental concentrations (Fig. 8) and higher $\delta^{234} U$ (Fig. 9) during slower drip rates in the winter months. Drier cave climate at these drip sites during winter months is consistent with high concentrations of elements in the drip water due to evaporation or prior $\mathrm{CaCO}_{3}$ precipitation. Slower drip rates during winter is also consistent with lower infiltration rates that drive high $\delta^{234} \mathrm{U}$ values of drip water.

At site $\mathrm{WBC} 1, \mathrm{\delta}^{234} \mathrm{U}$ of the top two years of stalagmite BC8 calcite has a value between the higher winter values and lower summer values of the corresponding

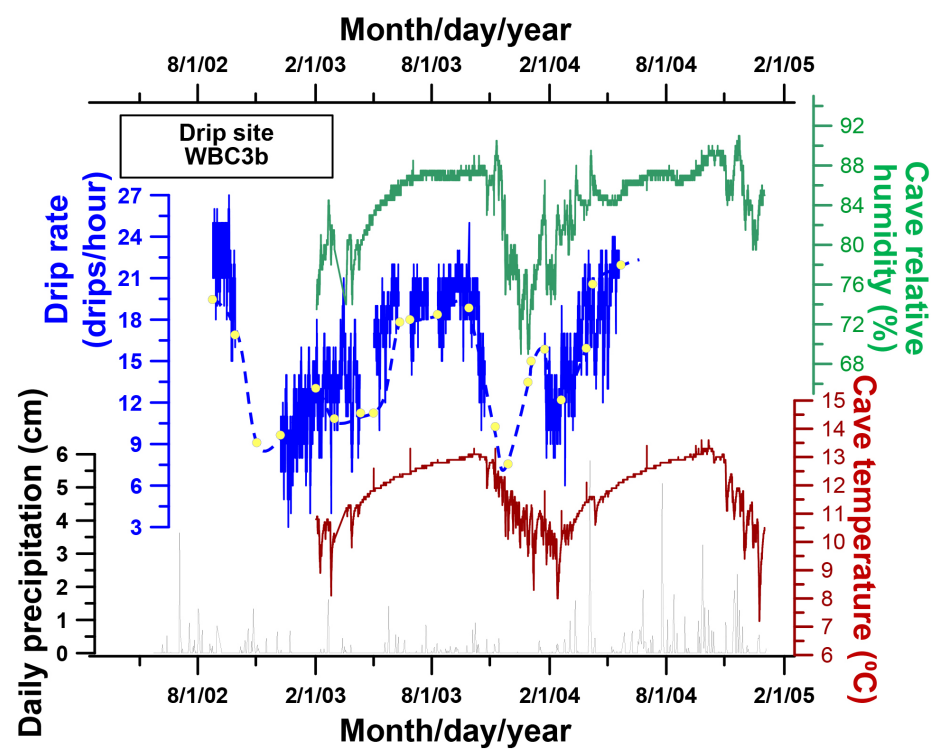

Fig. 6. Drip rate record for site WBC3b compared to cave relative humidity and cave temperature records for the same period. The dashed curve is the drip rate measured once per month at the time of download. Surface precipitation (rainfall) data are from Western Regional Climate Center (2013). Yellow circles and blue dashed curve represent manually measured drip rate data.

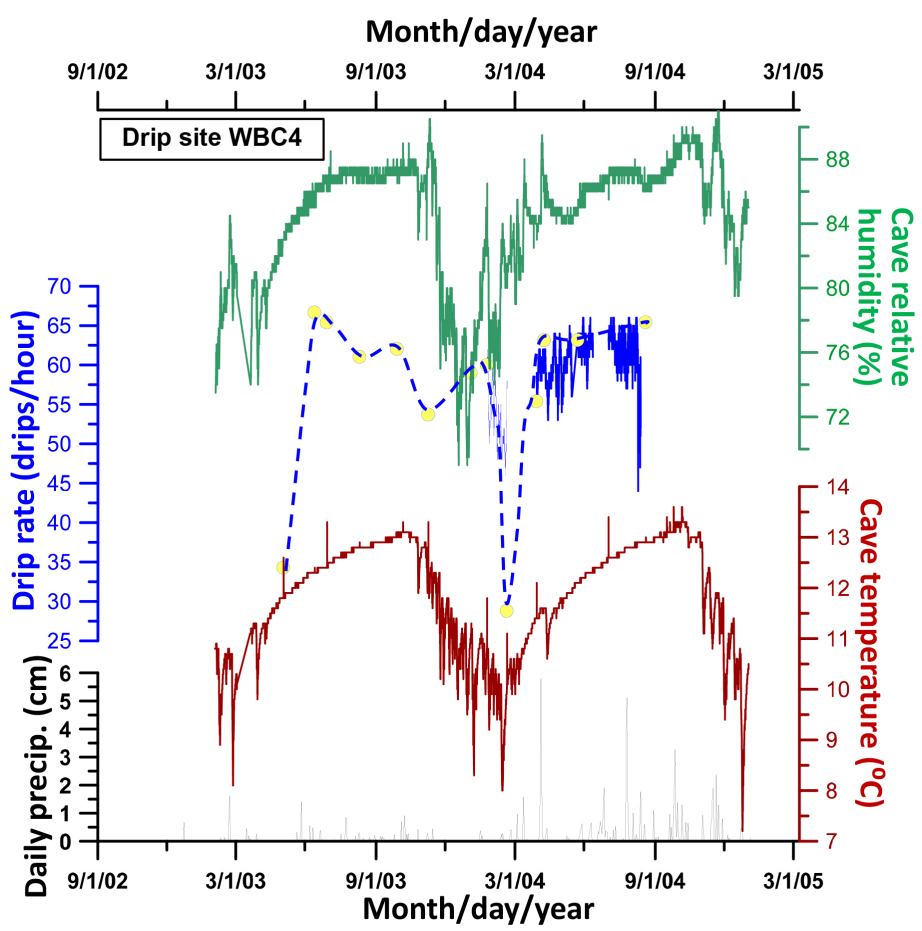

Fig. 7. Drip rate record for site WBC4 compared to cave relative humidity and cave temperature records for the same period. The dashed curve is the drip rate measured once per month at the time of download. Yellow circles and blue dashed curve represent manually measured drip rate data. The drip counter was placed late in this study.

drip water, showing that at site WBC1 deposition of calcite is likely occurring during all seasons, but predominantly in the spring and summer seasons. $\mathrm{U}$ concentration is negatively correlated with $\delta^{234} \mathrm{U}$ in WBC1 drip water (Fig. 9). Stalagmite BC11, collected from a different drip site after the drip study, has similar $\delta^{234} U$ values. The degree of $\delta^{234} U$ changes is a response to hydrological variation (Hellstrom \& McCulloch, 2000) suggesting that sites with similar $\delta^{234} U$ have comparable plumbing. These changes could occur from seasonal cessation of dripping, where winter season drip rates were more important than summer season, or they could result simply from drier/wetter annual periods (Polyak et al., 2012; Cross et al., 2015). Th isotope values for WBC 1 drip waters are also included in Fig. 9, and give insight into initial ${ }^{230} \mathrm{Th} /{ }^{232} \mathrm{Th}$ atomic ratios used to correct U-series dates.

Drip site WBC2, only 5 meters from WBC1, did not drip during the winter months over the monitoring period, showing that stalagmite growth could be sensitive to differences in seasonal dripping periods. This would suggest, for instance, that two stalagmites from the same cave room could produce significantly different geochemical proxy records, even though these records might uniquely record the same climate signal. Elemental, $\delta^{234} \mathrm{U}$, and probably stable isotope values should be different in a sample that grew from summer-only dripping, compared to a sample that grew from summer and winter dripping, and would be higher for elemental values during drier climate, where oscillations primarily follow decadal drivers such as PDO (Rasmussen et al., 2006; Asmerom et al., 2013). Seasonal values of drip water are complicated by infiltration times and evaporative conditions in the caves. 


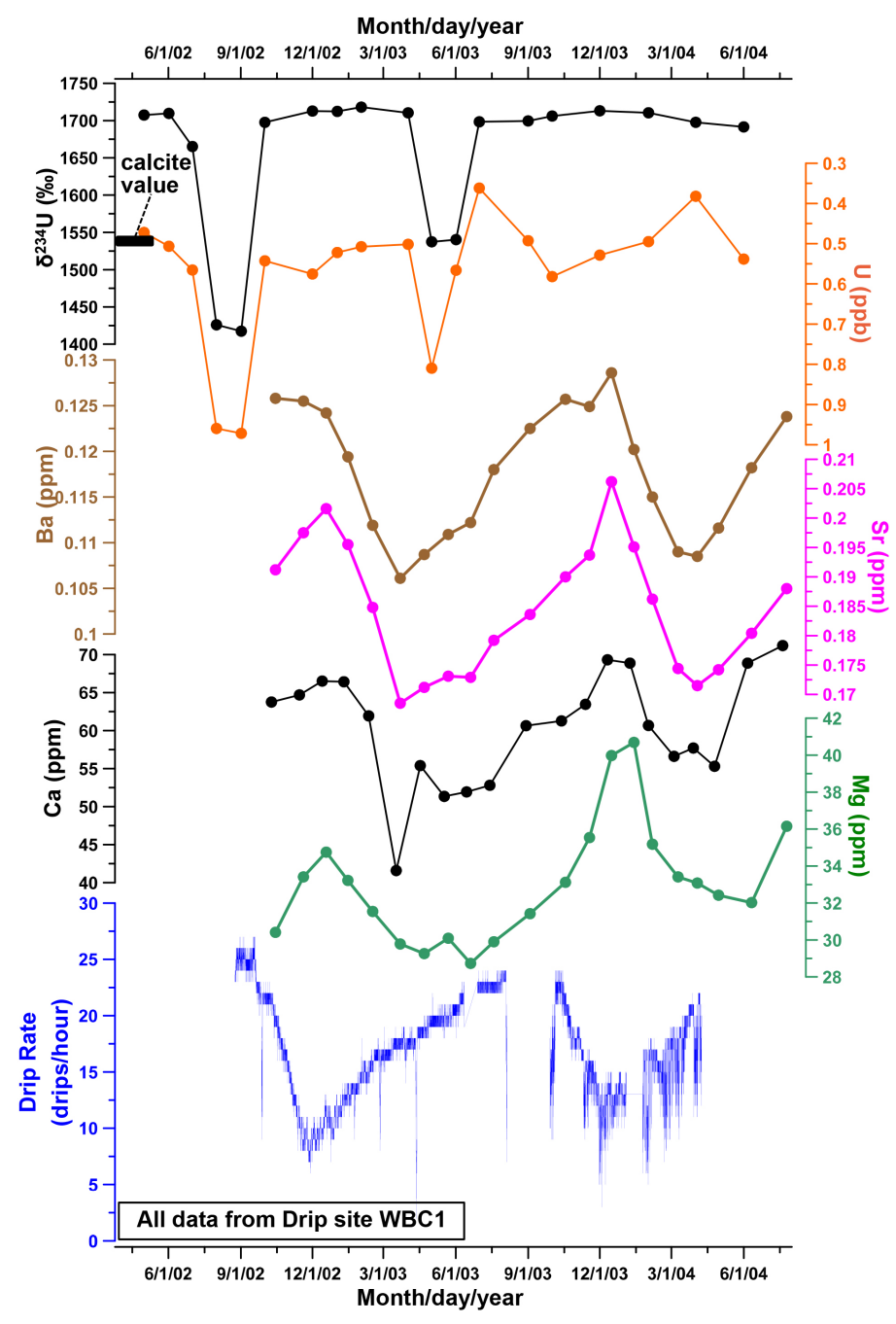

Fig. 8. Comparison of $\mathrm{Mg}, \mathrm{Ca}, \mathrm{Sr}, \mathrm{Ba}, \mathrm{U}$ concentrations, and $\delta^{234} \mathrm{U}$ for drip water of site WBC1 showing higher values during winter months when drip rates are lower. All y-axes are increasing in value upward except for $\mathrm{U}$ concentration.

A comparison of $\mathrm{Ca}$ concentration and $\mathrm{Mg} / \mathrm{Ca}, \mathrm{Sr} /$ $\mathrm{Ca}$, and $\mathrm{Ba} / \mathrm{Ca}$ shows that these ratios increase as $\mathrm{Ca}$ concentrations decrease in the WBC1 drip water (Fig. 10). Johnson et al. (2006) suggest that strong covariance of $\mathrm{Mg} / \mathrm{Ca}, \mathrm{Sr} / \mathrm{Ca}, \mathrm{Ba} / \mathrm{Ca}$, and $\mathrm{U} / \mathrm{Ca}$ in stalagmites is linked to both increased $\mathrm{CO}_{2}$ degassing combined with calcite precipitation on the stalagmite surface, and/or prior calcite precipitation before drip waters impact stalagmites. While evaporation could play a role, prior $\mathrm{CaCO}_{3}$ precipitation is the likely cause of decreased $\mathrm{Ca}$ concentrations and disproportionate increases in $\mathrm{Mg} / \mathrm{Ca}, \mathrm{Sr} / \mathrm{Ca}$, and $\mathrm{Ba} /$ $\mathrm{Ca}$ in our WBC1 drip water. The monthly anomaly that indicates prior $\mathrm{CaCO}_{3}$ took place was a winter month in $2003 \mathrm{CE}$, during a particularly dry year. It suggests, in agreement with Johnson et al. (2006), that dry climate leads to increased prior $\mathrm{CaCO}_{3}$ precipitation. Oster et al. (2012) suggest that a strong positive correlation between $\mathrm{Mg} / \mathrm{Ca}$ and $\mathrm{Sr} / \mathrm{Ca}$ in drip water is an indication of prior $\mathrm{CaCO}_{3}$ precipitation and this pattern should also be preserved in stalagmite $\mathrm{CaCO}_{3}$ (Oster et al., 2012).

\section{Initial ${ }^{230} \mathbf{T h} /{ }^{232} \mathrm{Th}$}

The ${ }^{230} \mathrm{Th} /{ }^{232} \mathrm{Th}$ atomic ratios and corresponding ${ }^{232} \mathrm{Th}$ concentrations (ppt) were measured for 20 monthly water samples collected at site WBC1.
Stalagmite studies commonly assume an initial ${ }^{230} \mathrm{Th} /{ }^{232} \mathrm{Th}$ atomic ratio value (time $=0$ ) to be $4.4 \mathrm{ppm}$ (0.0000044) used to correct uranium-series dates (Dorale et al., 2004). However, in our study area, the initial ${ }^{230} \mathrm{Th} /{ }^{232} \mathrm{Th}$ atomic ratios were measured to be higher (4.4 to $100 \mathrm{ppm}$ ) and varied with ${ }^{232} \mathrm{Th}$ concentration, where the ${ }^{230} \mathrm{Th} /{ }^{232} \mathrm{Th}$ atomic ratio decreases non-linearly as ${ }^{232} \mathrm{Th}$ concentrations increase (Fig. 9B; Polyak \& Asmerom, 2009). This was modeled as the high value end member Th source being the bedrock and the low value end member Th source being the soil. Recently, closed and open stable isotope systems have been modeled similarly, with the closed system (percolating water isolated from soil $\mathrm{CO}_{2}$ reservoir) causing higher $\delta^{13} \mathrm{C}$ values in speleothem $\mathrm{CaCO}_{3}$ due to greater input from bedrock carbon, and an open system causing lower $\delta^{13} \mathrm{C}$ values in speleothem $\mathrm{CaCO}_{3}$ due to greater input from soil carbon (McDermott, 2004). Greater initial ${ }^{230} \mathrm{Th} /{ }^{232} \mathrm{Th}$ atomic ratio values would seemingly be predicted in samples that have higher than expected $\delta^{13} \mathrm{C}$ values (i.e., closed system samples). Our drip waters yield values that are consistent with our study of stalagmite $\mathrm{CaCO}_{3}$ from this region, where ${ }^{230} \mathrm{Th} /{ }^{232} \mathrm{Th}$ atomic ratio decreases non-linearly as ${ }^{232} \mathrm{Th}$ concentrations increase (Fig. 9B).

\section{Volume of individual drips}

We determined drip volume at two sites based on number of drips counted versus monthly volume collected. The volume is therefore a monthly average.

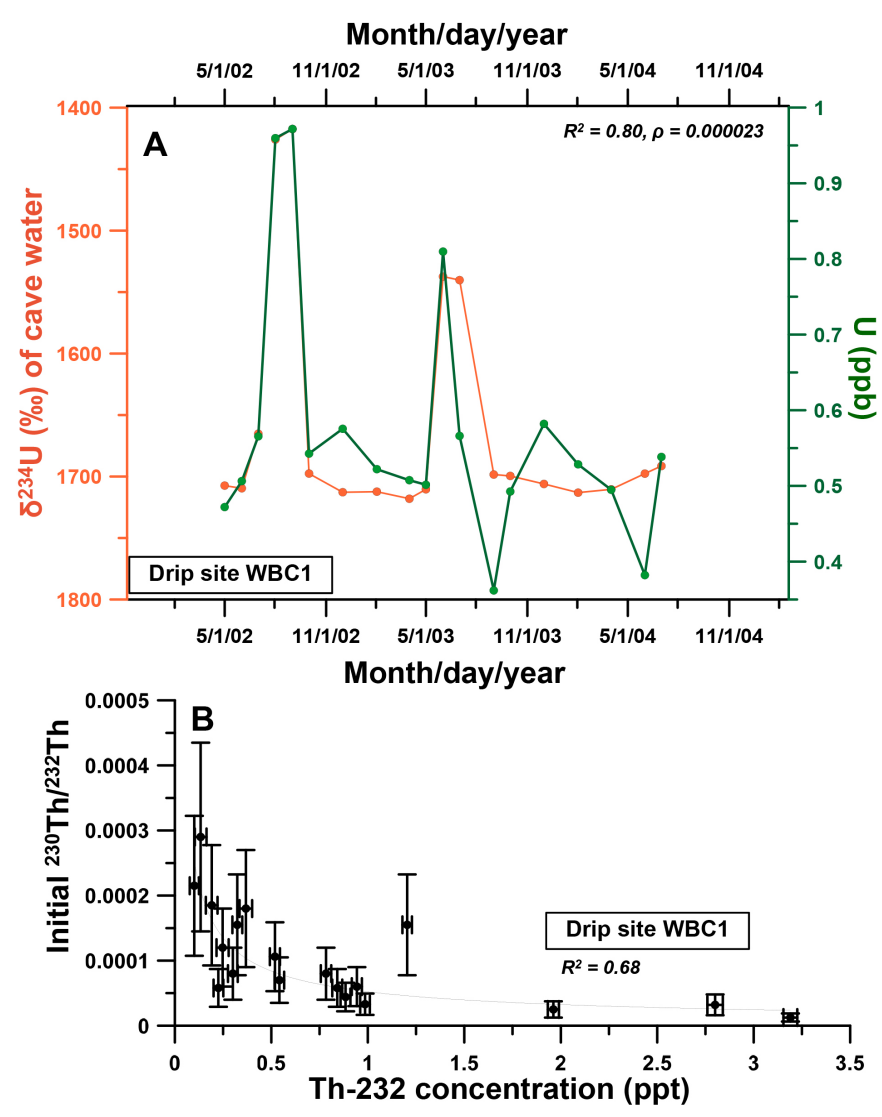

Fig. 9. A) Drip water $\delta^{234} \cup$ versus $U$ concentration exhibits negative correlation; B) ${ }^{232} \mathrm{Th}$ concentration versus initial ${ }^{230} \mathrm{Th} /{ }^{232} \mathrm{Th}$ values shows a nonlinear relationship. Note that the $\delta^{234} \mathrm{U}$ of newly formed calcite at the top of stalagmite BC-8 has a value suggesting that most calcite precipitation from this drip site took place during the spring or summer months. 
Month/day/year

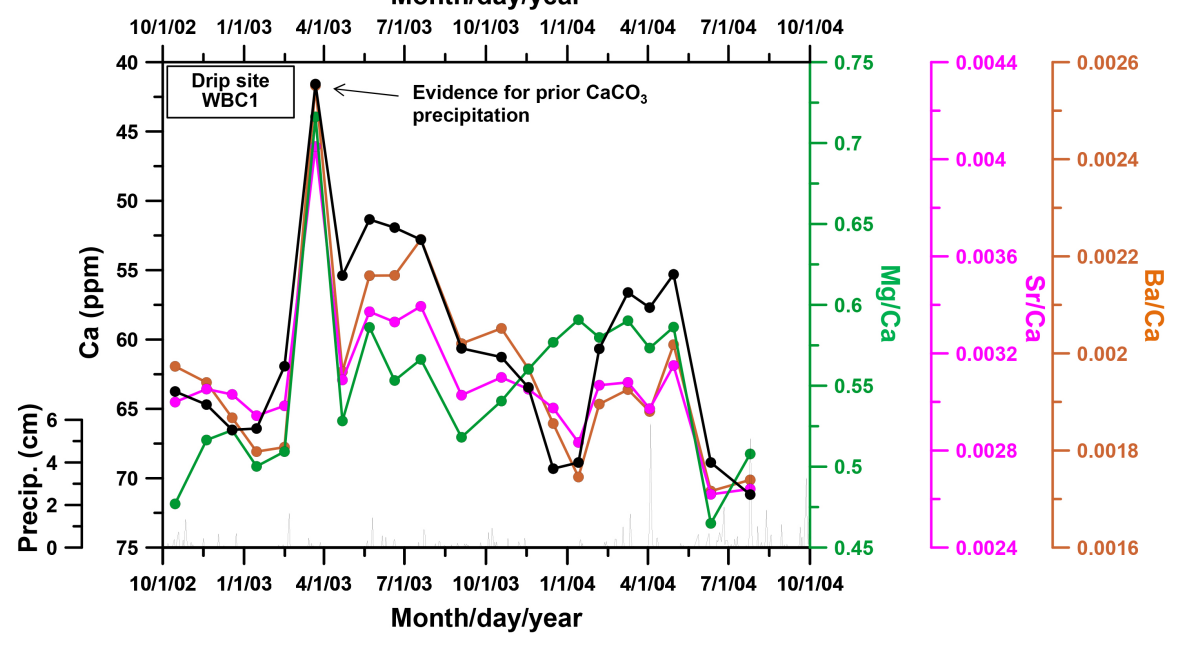

Fig. 10. Ca concentration in comparison to $\mathrm{Mg} / \mathrm{Ca}, \mathrm{Sr} / \mathrm{Ca}$, and $\mathrm{Ba} / \mathrm{Ca}$ for drip site $\mathrm{WBC} 1$. An anomaly in March of 2003 CE is produced by a deficiency in Ca relative to the other elements, for which prior $\mathrm{CaCO}_{3}$ precipitation would explain.

At site $\mathrm{WBC} 1$ and $\mathrm{WBC} 3 \mathrm{~b}$, drip volumes were measured to be $0.087 \pm 0.005 \mathrm{ml} /$ drip $(\mathrm{n}=5$ ), and $0.057 \pm 0.008 \mathrm{ml} /$ drip $(\mathrm{n}=6)$, respectively, which is less than the $0.17 \mathrm{~cm}^{3}(\mathrm{ml}) /$ drip reported by Baker et al.(1997) as typical, and the $0.114 \mathrm{ml} /$ drip reported by Genty \& Deflandre (1998). This difference in volume between WBC1 and WBC3b is presumably because of the shape of the surface were the drip originates (Tate, 1864). This was quantitatively determined by Collister $\&$ Mattey (2008) to be $\mathrm{m}=0.0255 \mathrm{r}+0.00981$ for stalactites, where, $\mathrm{m}=$ mass in grams $(1 \mathrm{ml}$ of water $=\sim 1$ gram) and $r=$ radii of the drip tube/surface. Their formula would suggest that drip sites WBC1 and WBC3b were fed by stalactites or sharp projections having diameters of 6.0 and $3.7 \mathrm{~mm}$, respectively, for which sizes are consistent with soda straw stalactites. Site $\mathrm{WBC} 1$ and $\mathrm{WBC} 3 \mathrm{~b}$ recorded similar drip rates, but our results suggest that site $\mathrm{WBC} 1$ having a larger drip volume delivers $50 \%$ more volume over time to the stalagmite.

Evaporation at the drip source (i.e., tip of soda straw), during the distance that the drip falls, at impact (including some loss of volume due to aerosol loss from the splash), and in the collection bottle could affect drip volume results that are measured using monthly bottle volumes. The standard errors on the mean drip volumes are low and show that the volume does not change linearly with volume of drip water in the collection bottles or with season, which would be the case if evaporation critically changed water volume in the bottles. While the effects from evaporation are somewhat significant in open pans even at 80 to $90 \%$ RH (McClean, 1971; Hill, 1987), we measured an 11 times less evaporation rate in the narrow-neck bottles than in open pans/bottles in the lab. Other factors mentioned above should change volumes at each site similarly. Therefore, we interpret that final results showing such big differences between drip volume at these two sites are meaningful.

\section{Cave and surface temperature}

There is a positive correlation between cave temperature and drip rate at all four drip sites, with all sites showing higher drip rates in the summer months as illustrated using site $\mathrm{WBC} 1$ drip versus surface and cave climatological data (Fig. 11). This would seemingly suggest a direct link between higher temperatures and increased effective precipitation, in some ways contrary to a previous interpretation that faster stalagmite growth correlates to wetter cooler climate (Polyak \& Asmerom, 2001). However, we suggest that the drip rate and seasonal surface temperature positive correlation is biased because seasonal increases in precipitation are linked to the summer monsoon, the period of maximum seasonal precipitation largely coincident with the period of maximum seasonal temperature. Seasonal correlation between temperature and drip rate is likely independent of long-term correlations between the two. In Figure 11, drip rate
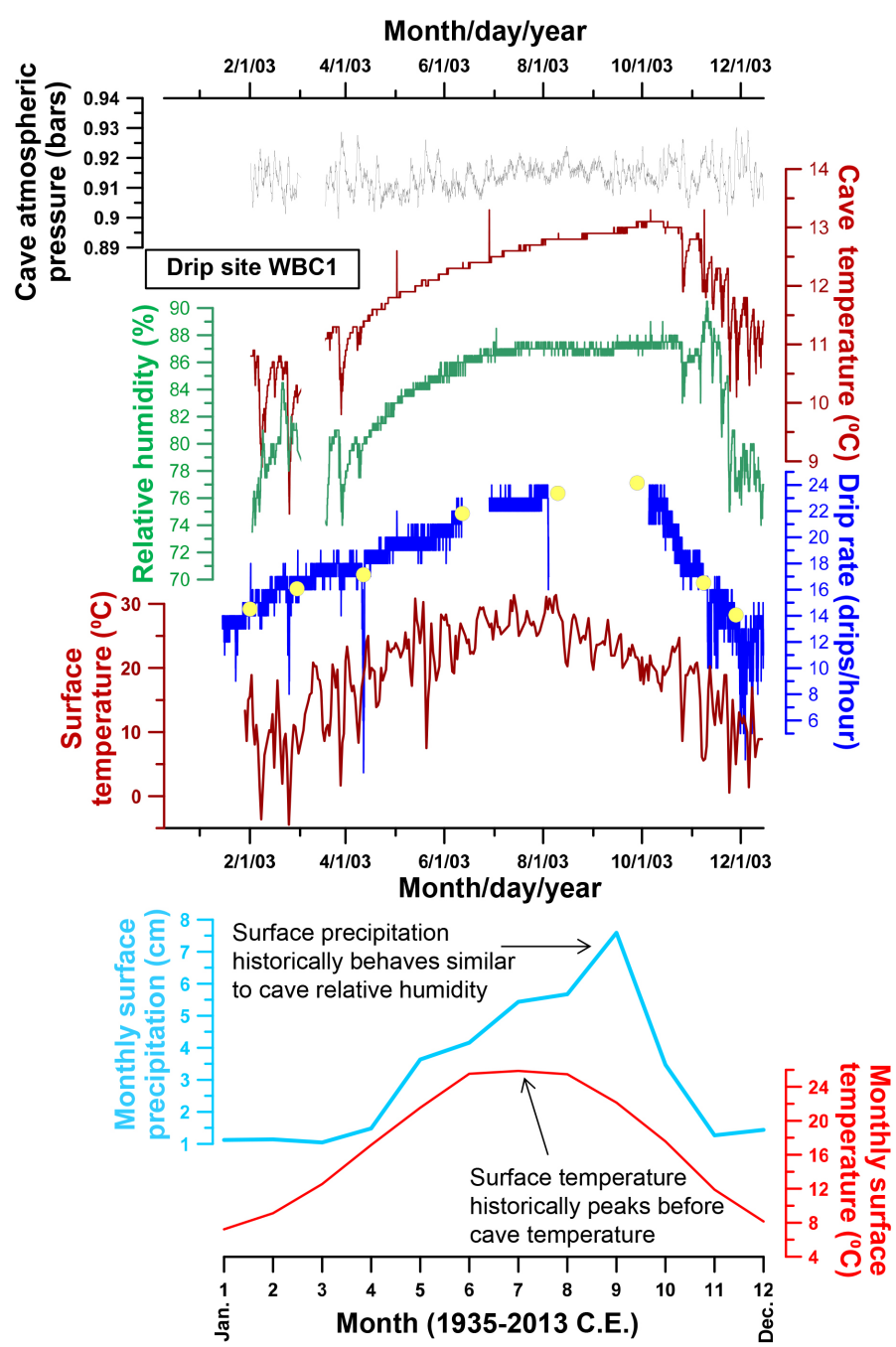

Fig. 11. Temperature, relative humidity, and site WBC1 drip rate show that seasonal variations correlate well with drip rate. The yellow circles are manual measurements of drip rate. The bottom graph shows the annual surface precipitation and temperature at Carlsbad Cavern from 1935 to $2013 \mathrm{CE}$ (Western Regional Climate Center, 2013), where month numbers 1 to 12 correspond to January to December average precipitation and temperature. There is a correlation between drip rate and surface precipitation via relative humidity in the cave shown by the blue bar. The lower graph represents the average of 78 years of climate data. Note that the drip rate starts falling before the cave temperature and relative humidity, and after the surface temperature, but more closely follows the surface precipitation. 
increases through summer, and continues to increase after surface temperatures begin cooling, and starts decreasing at the end of the summer monsoon in synchronization with surface and cave relative humidity, and cave temperature.

\section{Relative humidity at the drip sites}

There is a positive correlation between cave relative humidity and drip rate, with both having higher values in the summer months (Figs. 4-7, 11). This would suggest a link between increased effective precipitation and drip rates. Several studies show a very good correlation between drip rates and individual surface precipitation events (Oster et al., 2012; Khazmutdinova \& Nof, 2013; Poulain et al., 2015). However, like other drip rate studies (Onac et al., 2008; Casteel \& Banner, 2014), we have no obvious direct link between occurrences of precipitation events and drip rate (Rasmussen, 2006), but this could be partly due to the drip water collection period being within a lengthy period of drought that started in the early 1990s, although year $2002 \mathrm{CE}$ yielded near average precipitation and $2004 \mathrm{CE}$ yielded $\sim 40 \%$ above average precipitation. Like the correlation with temperature, the correlation with surface and cave relative humidity is seasonal and caused by the summer monsoonal months.

\section{Atmospheric pressure at the drip sites}

Overall correlation between cave atmospheric pressure and drip rate in the two longest drip records, $\mathrm{WBC} 1$ and $\mathrm{WBC} 3 \mathrm{~b}$, are $R^{2}=-0.0064$ and $R^{2}=-0.017$, respectively (Rasmussen, 2006), but during the winter and spring months there is a significant negative correlation showing that drip rate responds to changes in cave pressure. Drip site WBC4 had good correlation between drip rate and cave pressure in both spring and summer, and exhibits an hourly untuned correlation of $\mathrm{R}^{2}$ $=0.57$ and $R^{2}=0.44$, respectively, for a one to two month period (Fig. 12). Temperature and relative humidity in the cave did not respond the same, although individual storms can significantly lower the cave temperature at the drip sites. Genty \& Delflandre (1998) saw this same relationship for drip sites having <200 drips per hour. Low pressure systems (storms) during the winter and spring months result in increased drip rates during those events at our monitoring site. Other sites have recorded similar results (Baker \& Burnsdon, 2003; Fernández-Cortès et al., 2007; McCann, 2013; Tremaine \& Froelich, 2013). Spring and summer of 2003 show less variability (Fig. 11) than fall and winter.

Our results show that low pressure systems associated with storm events during the winter months cause measureable drip rate increases followed by decreases. This is followed by high pressure and corresponding decreasing drip rates. This negative

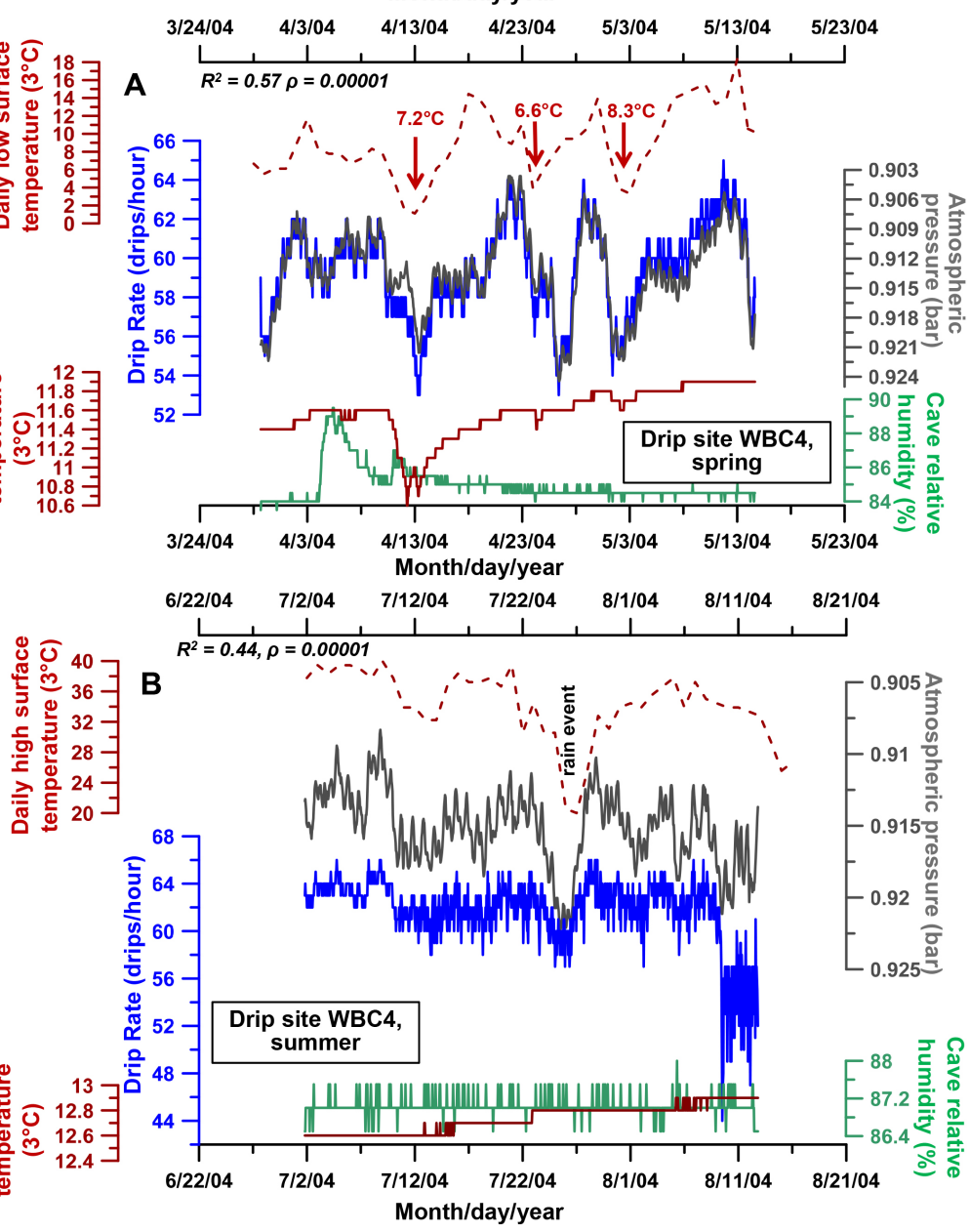

Fig. 12. A) Comparison of the WBC4 drip rate and cave atmospheric pressure during early spring $(A)$ and summer $(B)$ demonstrates the effects that pressure has on drip greatest during the winter and spring months. Correlation coefficients for drip rate versus atmospheric pressure are labeled in both $(A)$ and $(B)$. In $(A)$, early spring torms indicated by surface daily low-temperatures (red dashed curve; 7.2, 6.6,

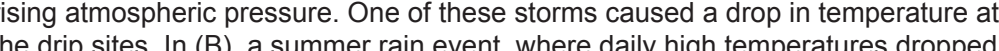
significantly, are coincident with changes in drip rate and atmospheric pressure as well. Weather data for the city of Carlsbad (red dashed curve) are from the Western Regional Climate Center (2013). Temperature and relative humidity at the drip sites were not affected by this rain storm event.

correlation between drip rate and atmospheric pressure shows that drip rate increases during shortterm decreases in pressure due to individual winter and spring storm systems. This correlation is not so clearly observed during the summer months, but we interpret from these results that summer monsoons having more storm events will have an overall lower seasonal atmospheric pressure, and therefore we interpret an indirect or less obvious tie of the drip rate to seasonal changes in atmospheric pressure rather than individual rainfall events.

\section{Spectral signals}

Analyses using Redfit (Schulz \& Mudelsee, 2002) of fall and winter data show that drip rate and atmospheric pressure share the same diurnal periodicities of 24, 12, and $\sim 3$ hours, and both show an $\sim 7$-day periodicity (Fig. 13). Analyses of cave humidity and temperature data do not show the diurnal periodicity, but also show the $\sim 7$-day signal. The 7 -day periodicity could be related to increased visitation to the cave 
on weekends. However, significant changes in both atmospheric pressure and temperature strongly indicate that these changes in the cave are driven by winter storms that push cold air into Carlsbad Cavern's large entrance. Significant drops in daily low temperature accompanied by changes in atmospheric pressure associated with the storm events on the surface match these excursions measured in the cave (Fig. 12).
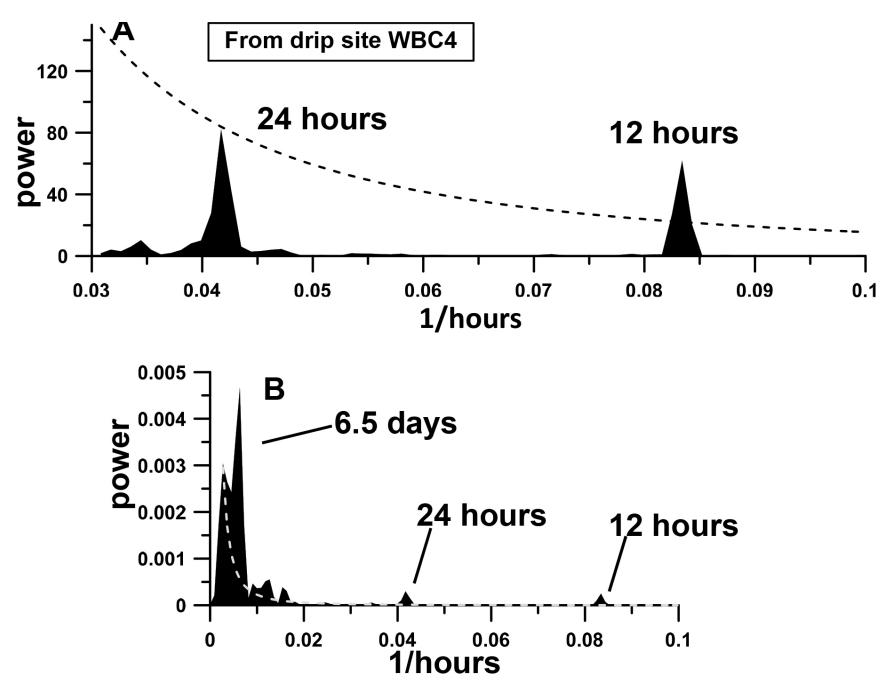

Fig. 13. Spectral analyses show the (A) periodicity of drip variability and (B) cave atmospheric pressure of drip site WBC4, with dashed lines representing $95 \%$ confidence.

\section{DISCUSSION}

Our drip study results show hourly to seasonal variability. The Carlsbad Cavern drip sites are similar to the seasonal and medium variability drip sites reported by Duan et al., 2016. In their study which focused primarily on oxygen stable isotope values of 34 drip sites from eight caves, only $12 \%$ were defined as seasonal type drip sites and $6 \%$ were defined as medium-variability drip sites, while $82 \%$ of the drip sites were described as static and did not show significant variability over a three-year period. Most of their cave sites also experienced distinctly greater rainfall events seasonally, for which drip sites seemed to have responded. Our sites are relatively close to Carlsbad Cavern's big entrance and some variability in our drip data was expected due to cold winter air sinking into the cave in winter and warm moist monsoonal air circulating through the cave during the summer. Hourly to weakly variability was likely caused by individual storm events, and are interpreted to be mainly caused by atmospheric pressure changes and not individual storm event precipitation amount (Rasmussen, 2006). The seasonal variability is not directly related to individual storm or rainfall events, but rather related to seasonal changes driven by relative humidity, and temperature. These seasonal changes translate to annual banding in stalagmites of the study area and are tied to regional climate change more so than local individual climate events.

While temperature correlates best with drip rate (positive correlation) in our two-year study ( $\mathrm{R} 2=0.76$, $\rho=0.00001$ for site WBC1; Rasmussen, 2006), we suggest that it is a seasonal relationship, and that temperature itself is not directly causing increased drip rates, because over the long-term and annually, the correlation between temperature and drip rate is likely negative. For instance, greater spring and summer rainfall is correlated to cooler spring and summers (Fig. 14) in the historical period, not warmer spring and summers (Western Regional Climate Center, 2013). Personal observation shows that in general wetter spring and summers result in wetter caves. Temperature alone is not driving variations in drip rate, but rather that the relative humidity is positively correlated to drip rate, and that higher summer temperatures occurring during every monsoon season indirectly drive drip rates. For example, higher relative humidity in the cave and on the surface occurs during the summer months when monsoonal flow and temperatures are higher. So we interpret that it is mostly a seasonal coincidence that temperatures are higher during periods of higher drip rate.

Dry hot summers equate to higher evaporation and less moisture available to enter the joints that serve as conduits for ground water infiltrating from the surface into the cave. Our monitoring period did not experience any abnormally wet winter precipitation, and drip rates slowed significantly or stopped during winter months, so our drip rate results would suggest that winter may equate to less or no calcite growth simply because of moisture deficit in the cave. Therefore, while drip rates correlate best with cave and surface temperatures seasonally, long-term correlations are related to spring and summer periods where cooler spring-summer periods equate to overall greater seasonal precipitation, and therefore equate to higher drip rates. This is indirectly consistent with wetter years equaling thick annual bands suggested by Polyak \& Asmerom (2001).

The warmer monsoonal season may cause higher drip rates in other ways. We introduce an additional interpretation that invokes monsoonal moisture and 'infiltration system relaxation' during the summer months that cause the infiltration routes to open up

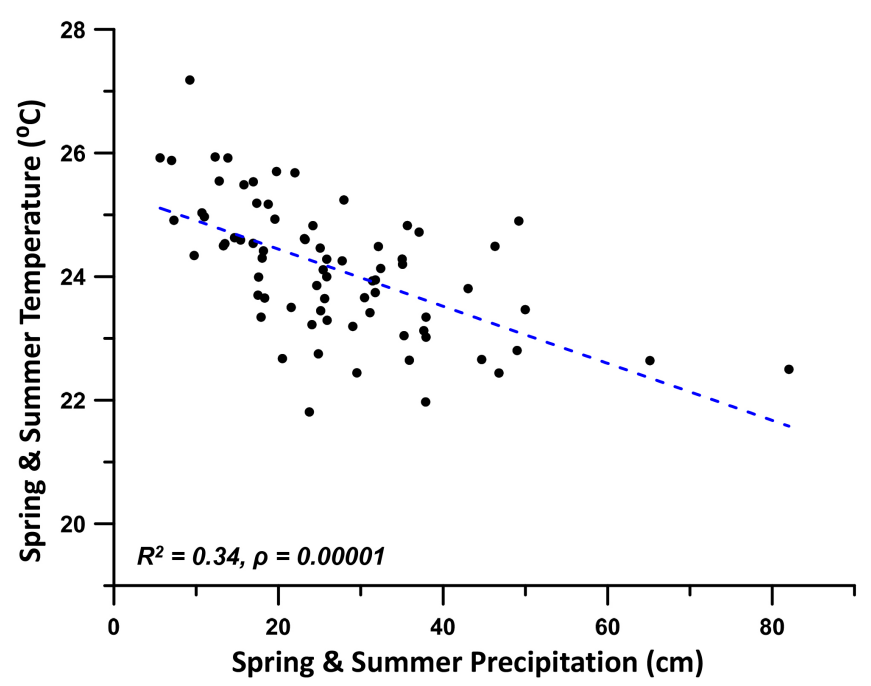

Fig. 14. Carlsbad Caverns spring-summer temperature versus precipitation for 72 of the 77 years from 1935 to 2013 shows a significant negative correlation. Cooler spring-summers represent wetter spring-summers. Data are from the Western Regional Climate Center (2013). 
or 'relax' enough to allow greater amounts of water to infiltrate through the bedrock overburden. In this hypothetical interpretation, higher relative humidity and higher effective rainfall would further enhance variations in drip rate. This relaxation is likely related to thermal expansion of the bedrock surface (Yan et al., 2009), increased organic activity within joints (i.e., root wedging; Maeght et al., 2013), physical variations of joint-filling materials by wetting/drying cycles (Dahan et al., 2000), and decreased surface tension and viscosity of water during the warmer months (Shukla, 2013), all more effective during the monsoonal months. In this way, higher drip rates during the summer months are directly related to infiltration system relaxation and increased relative humidity, both of which we expect to be enhanced by greater precipitation and more storm events.

Our area is moisture-limited, meaning that during very dry periods, the caves dry up, and as a consequence drip rates decrease or stop. So intuitively, higher precipitation means greater supply of water into the infiltration system, and therefore faster drip rates. However, we did not find a direct link between drip rate and precipitation event amount. But instead, the more indirect link is likely robust. During summer months, drip rates increase, not due directly to local temperature, but to increased relative humidity and relaxation of the infiltration systems related to the monsoonal period. Atmospheric pressure likely plays a long-term role and is related to climatic oscillations such as Pacific Decadal Oscillation and El Niño Southern Oscillation. Wetter seasonal cave climate should be caused by a greater number of storms and not solely correlated to precipitation amount from those storms. Thus we argue that spring-summer periods with more storms and moisture are cooler than spring-summer periods with less storms and moisture.

\section{CONCLUSION}

Our drip and stalagmite sites in Carlsbad Cavern are relatively close to the cave's large entrance, and yielded climate data that shows this area of Bat Cave Passage near the Main Corridor is an evaporative cave zone. Two drip sites exhibited drip rates between 10 and 30 drips per hour, and one drip site measured drips between 30 and 70 drips per hour. A fourth drip site had the highest drip rate (up to 280 drips per hour), but quit dripping in the winter months. At these sites, relative humidity varies seasonally from $\sim 90 \%$ in the summer to $\sim 80 \%$ in the winter, and temperature changes from $\sim 13^{\circ} \mathrm{C}$ in the summer and $\sim 11^{\circ} \mathrm{C}$ in the winter. Atmospheric pressure changes match those at the surface, and during winter months, there is a high correlation between pressure and drip rate changes. Elemental concentrations and $\delta^{234} \mathrm{U}$ in the drip water change seasonally with higher concentrations and lower $\delta^{234} \mathrm{U}$ values during winter months. Because our study area is moisture limited compared to more humid regions, more atmospheric moisture means faster drip rates. Our interpretation is that the higher temperature associated with the monsoonal period causes higher drip rates due to infiltration system relaxation and increased seasonal humidity that is associated with spring and summer storms. We predict that annual dripping will decrease during years with drier, hotter spring and summers. Therefore, cooler, wetter spring and summer periods represent greater effective moisture and increased drip rates in these caves. Exceptionally wet winters should also translate to faster drip rates as well, but this did not occur during our study period. A direct link between precipitation and drip rate is not necessary, but may play a small role as well.

\section{ACKNOWLEDGMENTS}

Our engineer, the late Bob Macy designed and built our drip monitors. Installation, drip water collection and collection of stalagmites $\mathrm{BC} 2$ and $\mathrm{BC} 7$ were permitted through Carlsbad Caverns National Park. We thank D. Pate, S. Allison, T. Bemis and P. Burger for coordination and field support during this study. We also thank $Z$. Rasmussen and P. Provencio for field assistance. This material is based upon work supported under a National Science Foundation Graduate Research Fellowship (J.B.T.R.), and by NSF grant ATM-0214333 (V.P. and Y.A.). We are grateful to three anonymous reviewers who helped improve this paper.

\section{REFERENCES}

Asmerom Y., Polyak V.J., Burns S.J. \& Rasmussen J.B.T., 2007 - Solar Forcing of Holocene Climate: New Insights from a Speleothem Record, southwestern United States. Geology, 35 (1): 1-4.

https://doi.org/10.1130/G22865A.1

Asmerom Y., Polyak V.J., Rasmussen J.B.T., Burns S.J. \& Lachniet M., 2013 - Multidecadal to multicentury scale collapses of Northern Hemisphere monsoons over the past millennium. Proceedings of the National Academy of Sciences, 110 (24): 9651-9656. https://doi.org/10.1073/pnas.1214870110

Baker A., Barnes W.L. \& Smart P.L., 1997 - Variations in the discharge and organic matter content of stalagmite drip waters in Lower Cave, Bristol. Hydrological Processes, 11: 1541-1555.

https://doi.org/10.1002/(SICI) 1099-1085(199709)11: 11\%3C1541::AID-HYP484\%3E3.0.CO;2-Z

Baker A. \& Brunsdon C., 2003 - Non-linearities in drip water hydrology: an example from Stump Cross Caverns, Yorkshire. Journal of Hydrology, 277: 151-163. https://doi.org/10.1016/S0022-1694(03)00063-5

Baldini J.U.L., McDermott F. \& Fairchild I.J., 2006 Spatial variability in cave drip water hydrochemistry: Implications for stalagmite paleoclimate records. Chemical Geology, 235 (3-4): 390-404.

https://doi.org/10.1016/j.chemgeo.2006.08.005

Beddows P.A., Schwarcz H.P., Zhang R. \& Ford D.C., 2007 - Cave-drip monitoring as a foundation for better paleoclimate reconstruction. In: Elliot W.R. (Ed.), Proceedings of the 2007 National Cave and Karst Management Symposium, St. Louis, USA. 204-211.

Casteel R.C. \& Banner J.L., 2014 - Temperature-driven seasonal calcite growth and drip wter trace element variations in a well-ventilated Texas cave: Implications for speleothem paleoclimate studies. Chemical Geology, 392: 43-58.

https://doi.org/10.1016/j.chemgeo.2014.11.002 
Collister C. \& Mattey D., 2008 - Controls on water drop volume at speleothem drip sites: An experimental study. Journal of Hydrology, 358: 259-267. https://doi.org/10.1016/j.jhydrol.2008.06.008

Cross M., McGee D., Broecker W.S., Quade J., Shakun J.D., Cheng H., Lu Y. \& Edwards R.L., 2015 - Great Basin hydrology, paleoclimate, and connections with the North Atlantic: A speleothem stable isotope and trace element record from Lehman Caves, NV. Quaternary Science Reviews, 127: 186-198.

https://doi.org/10.1016/j.quascirev.2015.06.016

Dahan O., Nativ R., Adar E.M., Berkowitz B. \& Weisbrod N., 2000 - On fracture structure and preferential flow in unsaturated chalk. Ground Water 39 (3): 444-451. https://doi.org/10.1111/j.1745-6584.2000.tb00231.x

Dorale J.A., Edwards R.L., Alexander Jr. E.C., Shen C-C., Richards D.A. \& Cheng H., 2004 - Uraniumseries dating of speleothems: Current techniques, limits, \& applications. In: Sasowsky I.D. \& Mylroie J. (Eds.), Studies of cave sediments. Kluwer Academic/Plenum Publishers, New York, pp. 177-197. https://doi.org/10.1007/978-1-4419-9118-8_10

Duan W., Ruan J., Luo W., Li T., Tian L., Zeng G., Zhang D., Bai Y., Li J., Tao T., Zhang P., Baker A. \& Tan M., 2016 - The transfer of seasonal isotopic variability between precipitation and drip water at eight caves in the monsoon regions of China. Geochimica et Cosmochimica Acta, 183: 250-266.

https://doi.org/10.1016/j.gca.2016.03.037

Fairchild I.J., Tuckwell G.W., Baker A. \& Tooth A.F., 2006 - Modelling of dripwater hydrology and hydrogeochemistry in a weakly karstified aquifer (Bath, UK): Implications for climate change studies. Journal of Hydrology, 321: 213-231.

https://doi.org/10.1016/j.jhydrol.2005.08.002

Fernández-Cortès A., Calaforra J.M., Sanchez-Martos F. \& Gisbert J., 2007. Stalactite drip rate variations controlled by air pressure changes: an example of nonlinear infiltration processes in the 'Cueva del Agua' (Spain). Hydrological Processes, 21: 920-930.

https://doi.org/10.1002/hyp.6283

Genty D. \& Deflandre G., 1998 - Drip flow variations under a stalactite of the Pére Noël cave (Belgium). Evidence of seasonal variations and air pressure constraints. Journal of Hydrology, 211: 208-232. https://doi.org/10.1016/S0022-1694(98)00235-2

Hill C.A., 1987 - Geology of Carlsbad Cavern and other caves in the Guadalupe Mountains, New Mexico and Texas. New Mexico Bureau of Mines and Mineral Resources, Bulletin, 117: 149 p.

Hellstrom J.C. \& McCulloch M.T., 2000 - Multi-proxy constraints on the climatic significance of trace element records from a New Zealand speleothem. Earth and Planetary Science Letters, 179: 287-297.

https://doi.org/10.1016/S0012-821X(00)00115-1

Johnson K.R., Hu C., Belshaw N.S. \& Henderson G.M., 2006 - Seasonal trace-element and stable-isotope variations in a Chinese speleothem: The potential for high-resolution paleomonsoon reconstruction. Earth and Planetary Science Letters, 244: 394-407. https://doi.org/10.1016/j.eps1.2006.01.064

Khazmutdinova K. \& Nof D., 2013 - Percolation into Dragon's Tooth Cave, Florida, USA. In: Bosak P., Filippi M. (Ed.), $16^{\text {th }}$ International Congress of Speleology Proceedings, Brno, 2: 417-422.

Lachniet M.S., 2009 - Climatic and environmental controls on speleothem oxygen isotope values: Quaternary Science Reviews, 28: 412-432.

https://doi.org/10.1016/j.quascirev.2008.10.021
Lachniet M.S., 2015 - Are aragonite stalagmites reliable paleoclimate proxies? Tests for oxygen isotope timeseries replication and equilibrium: Geological Society of America Bulletin. 127 (11-12): 1521-1533.

https://doi.org/10.1130/B31161.1

Leavitt S.W., Woodhouse C.A., Castro C.I., Wright W.E., Meko D.M., Touchan R., Griffin D. \& Ciancarelli B., 2011, The North American monsoon in the U.S. Southwest: Potential for investigation with tree-ring carbon isotopes. Quaternary International, 235: 101107. https://doi.org/10.1016/j.quaint.2010.05.006

Maeght J., Rewald B. \& Pierret A., 2013 - How to study deep roots - and why it matters. Frontiers in Plant Science, 4: 299.

https:// doi.org/10.3389/fpls.2013.00299

McCann S.C., 2013 - Atmospheric influences on cave meteorology, Jinapsan Cave, Guam: A drip rate analysis. Unpublished MS Thesis, Department of Geosciences, Mississippi State University, MS, 475 p.

McClean J.S., 1971 - The microclimate in Carlsbad Caverns, New Mexico. United States Geological Survey, Open File Report 71-198: 67 p.

McDermott F., 2004 - Palaeo-climate reconstruction from stable isotope variations in speleothems: a review. Quaternary Science Reviews, 23: 901-918.

https://doi.org/10.1016/j.quascirev.2003.06.021

McDonald J. \& Drysdale R.N., 2007 - Hydrology of cave drip waters at varying bedrock depths from a karst system in southeastern Australia. Hydological Processes, 21: 1737-1748. https://doi.org/10.1002/hyp.6356

Nymeyer R. \& Halliday W.R., 1991 - Carlsbad Cavern - The Early Years. Guadalupe Mountains Association, Carlsbad, New Mexico, 155 p.

Onac B.P., Pace-Graczyk K. \& Atudirei V., 2008 - Stable isotope study of precipitation and cave drip water in Florida (USA): implications for speleothem-based paleoclimate studies. Isotopes in Environmental and Health Studies, 44 (2): 149-161.

https://doi.org/10.1080/10256010802066174

Oster J.L., Montañez I.P. \& Kelley N.P., 2012 - Response of a modern cave system to large seasonal precipitation variability. Geochimica et Cosmochimica Acta, 91: 92108. https://doi.org/10.1016/j.gca.2012.05.027

Polyak V. J. \& Asmerom Y., 2001 - Late Holocene climate and cultural changes in the Southwestern United States. Science, 294: 148-151. https://doi.org/10.1126/science.1062771

Polyak V.J., Cokendolpher J., Norton R. \& Asmerom Y., 2001 - Wetter and cooler late Holocene climate in the southwestern United States from mites preserved in stalagmites. Geology, 29: 643-646.

https://doi.org/10.1130/0091-7613(2001)029\% 3C0643:WACLHC\%3E2.0.CO;2

Polyak V.J. \& Asmerom Y., 2009 - Overcoming initial ${ }^{230} \mathrm{Th}$ problems in uranium-series dating without using ${ }^{234} \mathrm{U} /{ }^{232} \mathrm{Th}-{ }^{230} \mathrm{Th} /{ }^{232} \mathrm{Th}$ isochrons. In: White W.B. (Ed.), Proceedings of the $15^{\text {th }}$ International Congress of Speleology, Kerrville, 2: 1060-1064.

Polyak V.J., Asmerom Y., Burns S.J. \& Lachniet M.S., 2012 - The climatic backdrop to the terminal Pleistocene extinction of North American mammals. Geology, 40 (11):1023-1026. https://doi.org/10.1130/G33226.1

Poulain A., Rochez G., Bonniver I. \& Hallet V., 2015 - Stalactite drip-water monitoring and tracer tests approach to assess hydrogeologic behavior of karst vadose zone: case study of Han-sur-Lesse (Belgium). Environmental Earth Sciences, 74: 7685-7697. https://doi.org/10.1007/s12665-015-4696-9 
Rasmussen J.B.T., 2006 - Late Holocene climate variability in the Southwestern United States from highresolution speleothem data. Unpublished $\mathrm{PhD}$ Thesis, University of New Mexico, Albuquerque, NM, 540 p.

Rasmussen J.B.T., Polyak V.J. \& Asmerom Y., 2006 Evidence for Pacific-modulated precipitation variability during the late Holocene from the southwestern USA. Geophysical Research Letters, 33: L08701. https://doi.org/10.1029/2006GL025714

Ridley H.E., Baldini J.U.L., Prufer K.M., Walczak I.W. \& Breitenbach S.F.M., 2015 - High-resolution monitoring of YOK Balum Cave, Belize: An investigation of seasonal ventilation regimes and the atmospheric and drip-flow response to a local earthquake. Journal of Cave and Karst Studies, 77 (3), 183-199.

https://doi.org/10.4311/2014ES0117

Schulz M. \& Mudelsee M., 2002 - REDFIT: Estimating red-noise spectra directly from unevenly spaced paleoclimatic time series. Computers \& Geosciences, 28: 421-426.

https://doi.org/10.1016/S0098-3004(01)00044-9

Shukla M.K., 2013 - Soil physics - An introduction. CRC Press, New York, 478 p.

Smart P.L. \& Friederich H., 1987 - Water movement and storage in the unsaturated zone of a maturely karstified carbonate aquifer, Mendip Hills, England. Proceedings of the Environmental Problems in Karst Terranes and their solutions Conference, KY, USA, 57-87.
Tate T., 1864 - On the magnitude of a drop of liquid formed under different circumstances. Philosophical Magazine Series, 27 (181): 176-180.

Tremaine D.M. \& Froelich P.N., 2013 - Speleothem trace element signatures: A hydrologic geochemical study of modern cave dripwaters and farmed calcite. Geochimica et Cosmochimica Acta, 121: 522-545.

https://doi.org/10.1016/j.gca.2013.07.026

Verheyden S., Genty D., Deflandre G., QuinifY. \& Keppens E., 2008 - Monitoring climatological, hydrological and geochemical parameters in the Pere Noel cave (Belgium): implication for the interpretation of speleothem isotopic and geochemical time-series. International Journal of Speleology, 37 (3): 221-234. https://doi.org/10.5038/1827-806X.37.3.6

Wang S., Huang J., He Y. \& Guan Y., 2014 - Combined effects of the Pacific Decadal Oscillation and El NinoSouthern Oscillation on global land dry-wet changes. Scientific Reports, 4: 6651. https://doi.org/10.1038/srep06651

Western Regional Climate Center, 2013 - Cooperative Climatological Data Summaries. Retrieved from http:// wrcc.dri.edu/climatedata/climsum/

Yan H., Chen W., Zhu Y., Zhang W. \& Zhong M., 2009 - Contributions of thermal expansion of monuments and nearby bedrock to observed GPS height changes. Geophysical Research Letters, 36: L13301. https://doi.org/10.1029/2009GL038152 